\title{
Characterization of household solid waste and current status of municipal waste management in Rishikesh, Uttarakhand
}

\author{
Suman Rawat, Achlesh Daverey ${ }^{\dagger}$ \\ School of Environment and Natural Resources, Doon University, Dehradun, Uttarakhand 248001, India
}

\section{ABSTRACT}

The municipal solid waste (MSW) management system in one of the Class II Indian cities i.e. Rishikesh was studied and analysed to identify the key issues in solid waste management in the city. A total of 329 solid waste samples from 47 households were collected to characterize the household solid waste (HSW). The average (HSW) generation rate was $0.26 \mathrm{~kg} / \mathrm{c} / \mathrm{d}$ and it was composed of organic waste $(57.3 \%)$, plastics $(14 \%)$, paper $(10.9 \%)$, and glass and ceramic $(1.3 \%)$ and other materials $(16.5 \%)$. There was an inverse relationship between household waste generation rate and family size $(p<0.05)$. The MSW management system practiced in Rishikesh is unsound. There is no waste segregation at source, no provisions of composting and no recycling by formal sector. The collection and transportation of waste is inadequate and inappropriate. Collected waste is dumped in open dumping site without scientific management. Following are some recommendations for developing a sustainable solid waste management system in Rishikesh city: (1) sensitize people for segregation at source; (2) promote reduction, reuse and recycling of wastes; (3) promote community based composting; (4) provision for 100\% door to door collection and; (5) formalize the informal sectors such as rag pickers and recycling industries.

Keywords: Household waste, Municipal solid waste, Rishikesh, Family size, Waste characteristics

\section{Introduction}

Municipal solid waste (MSW) management is a big challenge around the world especially for developing countries such as India. The population in Indian cities is increasing exponentially due to rapid urbanization and industrialization [1]. The community living standards in the Indian cities have been improved significantly in the recent past. These factors accelerated the generation rate of MSW in cities. Total solid waste generated by urban India is about 51 million metric tonnes as per the report of Central Pollution Control Board India (CPCB, 2014-15). The per capita waste generation rates vary between 0.2 to 0.6 $\mathrm{kg} / \mathrm{d}$ [2].

In India, MSW has been neglected by most of the urban local bodies (ULBs) and therefore, its management has become a challenge for ULBs to keep cities clean and hygiene. There could be multiple reasons for neglecting the MSW management such as lack of land availability for waste disposal and technological and financial limitations of ULBs, which affects the collection efficiency, transportation and scientific disposal of waste [3].

This is an Open Access article distributed under the terms of the Creative Commons Attribution Non-Commercial License (http://creativecommons.org/licenses/by-nc/3.0/) which permits unrestricted non-commercial use, distribution, and reproduction in any medium, provided the original work is properly cited.

Copyright (C) 2018 Korean Society of Environmental Engineers
Initiatives by Indian Government such as Clean India Mission (Swachh Bharat Mission) launched by Ministry of Housing and Urban Affairs, Government of India further stressed on ULBs to manage the MSW on urgent basis. Therefore, there is an urgent need to address the issues related to solid waste management in Indian cities.

Uttarakhand is an important hilly state of India. There are many pilgrimage sites in Uttarakhand and it is one of the fastest growing states of India. In spite of this, status of MSW generation and management of only few cities of Uttarakhand (Haridwar, Roorkee, Nainital) have been reported in literature [1, 4-6]. To the best of our knowledge, MSW management in Rishikesh city has not been reported so far. Therefore, the main objective of this study was to report and study the MSW generation and management system, quantification and characterization of daily household solid waste generation and correlation of household waste generation and family size in Rishikesh city. Based on the study, key recommendations for developing a sustainable solid waste management system in Rishikesh city are proposed.

\author{
$\dagger$ Corresponding author \\ Email: ach15may@gmail.com, achlesh.senr@doonuniversity.ac.in \\ Tel: +91-135-2533103
}

ORCID: 0000-0003-4480-0141 


\section{Methods}

\subsection{Description of the Study Area}

This study was conducted in Rishikesh, a town of Dehradun city of Uttarakhand and a Class II city of India. The city is just $35 \mathrm{~km}$ from the holy city Haridwar and $240 \mathrm{~km}$ from New Delhi, the Indian capital. Rishikesh is situated in the bank of holy river Ganga and foothills of Garhwal Himalayan Range. It is one of the important pilgrimage sites in India. The city is also equally popular for yoga and meditation. In recent years, the city has become the hotspot for adventure sports such as bungee jumping, rafting.

The Rishikesh municipality town covers an area of $10 \mathrm{sq}$. $\mathrm{km}$ and has 20 wards with total population of 70,379 as per census 2011. The municipality has around 7,500 household units, over 375 hotels/restaurants, about 1,600 shops and 269 ashrams (Municipal Corporation Rishikesh).

\subsection{Data Collection for the Status of MSW Management}

Field survey was conducted to know the status of MSW management in Rishikesh city. The data of total waste generated, waste collected and generation of MSW from different sectors such as household/domestic, commercial establishments and hotels were collected from Municipal Corporation Rishikesh. Details of vehicles for waste collection were also collected. Field survey of city was conducted to check the real status of waste collection and segregation, vehicles used, community bins in the city and the location of MSW dumping site.

\subsection{Household Waste Sampling}

In this study, 47 households from five different wards/area namely Ashutosh Nagar, Adarsh Gram, Gumani Wala, Bapu Gram and Dudhu Pani of Municipal Corporation Rishikesh were selected to collect the household waste. The five wards were selected based on the geographic (two from North, two from south and one from middle of the city) of the Rishikesh city. Easy road access was also considered before selecting the wards. Sampling of the selected household was done on random basis. The study was conducted in the month of May, 2016 (Level I) and June, 2016 (Level II). A total of 329 household waste samples (175 samples in Level I and 154 samples in Level II) were collected to study the household solid waste generation rate and its composition.

Sample collection was carried out in each selected household for eight consecutive days in two polythene bags. Persons of each family were instructed to use separate bags for biodegradable and non-biodegradable wastes. First day sample was collected and discarded to ensure that the waste used for analysis had been generated in the last $24 \mathrm{~h}$. The bags with the waste generated in each household was further segregated and weighed by using a spring balance $(5 \mathrm{~kg}$ ). Personal protective equipments such as gloves and mask were used during waste handling.

\subsection{Statistical Analysis}

Descriptive analysis of per capita household waste generation rate was performed to calculate the statistical parameters such as mean, minimum and maximum per capita waste generation rates, standard deviation, kurtosis and skewness. Analysis of variance (ANOVA) tests were also performed to evaluate the significance between family size and per capita household waste generation rate, and each day of week and household waste generated. The Data Analysis tool in Microsoft Excel 2016 was used for all statistical analysis such as ANOVA and descriptive statistics.

\section{Results and Discussion}

\subsection{MSW Generation and Management in Rishikesh}

The city generates about 30 MT of solid waste per day. Table 1 shows the MSW generation from different sectors in Rishikesh. Being a tourist place, hotels, slaughter houses, fish markets, shops and commercial establishments are the major sources of MSW generation in Rishikesh city apart from domestic waste.

Fig. 1 compares the per capita MSW generated by different cities of India [7]. The Rishikesh city $(0.278 \mathrm{~kg} / \mathrm{c} / \mathrm{d})$ generates the least amount of MSW per capita compared to other Indian cities with population less than 0.1 million such as Gangtok $(0.44 \mathrm{~kg} / \mathrm{c} / \mathrm{d})$, Daman $(0.42 \mathrm{~kg} / \mathrm{c} / \mathrm{d})$ and Panjim (0.54 kg/c/d). The city Nasik with population of 1.07 million, another important

Table 1. Generation of Solid Waste from Different Sector

\begin{tabular}{ll}
\hline \multicolumn{1}{c}{ Sector } & \multicolumn{1}{c}{ Waste generated } \\
\hline Total solid waste generated & $30.0 \mathrm{MT} / \mathrm{d}$ \\
Total collection of waste generated & $18.0 \mathrm{MT} / \mathrm{d}$ \\
MSW generation rate & $0.278 \mathrm{~kg} / \mathrm{c} / \mathrm{d}$ \\
Domestic waste generation & $1.0-3.0 \mathrm{~kg} /$ house/d \\
$\begin{array}{l}\text { Waste generated by shops and commercial } \\
\text { establishments }\end{array}$ & $1.0 \mathrm{~T} / \mathrm{d}$ \\
$\begin{array}{l}\text { Waste generated by hotels, slaughter } \\
\text { houses and fish markets }\end{array}$ & $2.0 \mathrm{~T} / \mathrm{d}$ \\
\hline
\end{tabular}

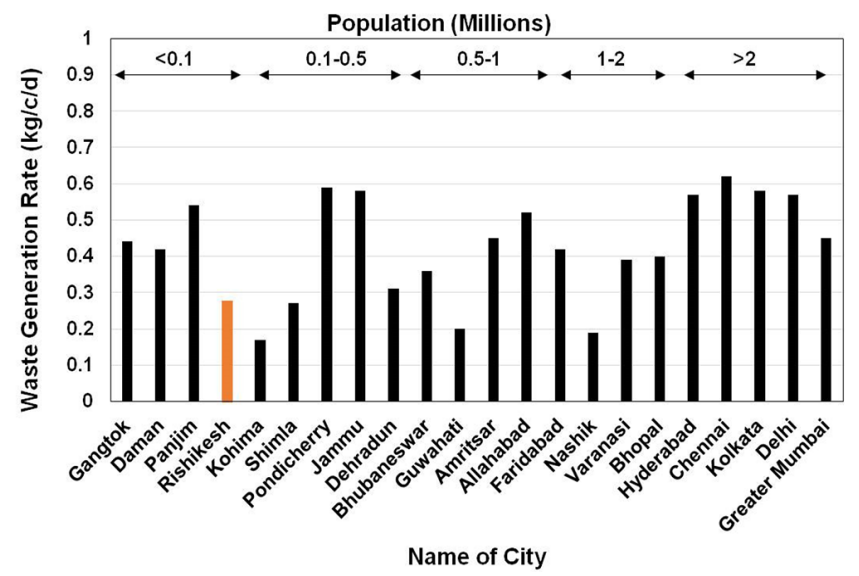

Fig. 1. Per capita MSW generated by different cities of India having different population. 
pilgrimage site, generates only $0.19 \mathrm{~kg} / \mathrm{c} / \mathrm{d}$ of waste. However, contrary to this, the city Varanasi (population of 1.09 million) generates higher per capita waste $(0.39 \mathrm{~kg} / \mathrm{c} / \mathrm{d})$ than Rishikesh. The per capita waste generated by all the metro cities $(>0.5$ $\mathrm{kg} / \mathrm{c} / \mathrm{d}$ except greater Mumbai) is much higher than Rishikesh. The Rishikesh city also generates lesser amount of per capita waste than other cities of Uttarakhand (Haridwar, $0.430 \mathrm{~kg} / \mathrm{c} / \mathrm{d}$; Dehradun, 0.310 kg/c/d; Roorkee, 0.330 kg/c/d; Nainital, 0.314 $\mathrm{kg} / \mathrm{c} / \mathrm{d}$ ) [1, 4-7].

It was learnt during the field visit that no one practices segregation of waste at source, which is the major drawback of the MSW management system in Rishikesh. It was observed that some of the waste collectors segregate reusable and recyclable wastes. Some street rag pickers segregate recyclable material such as plastics, glass, metallic/electronic items from community bins and sell them to the recycling factory.

The primary collection of MSW is being carried out by 136 sanitary workers. The sanitary workers use hand carts for door to door waste collection. The collected wastes from household and street sweeping are dumped in the community bins. Secondary collection of MSW is done through transporting vehicles (trucks, tractors, tricycles), which is then transported through truck to the dumpsite at Govind Nagar near truck union, Haridwar Road. The dumpsite covers about 16 acres of land area. Fig. 2 shows the images of the poor status of community bins and open dumping site. Stray animals such as pigs, dogs, cows etc. eat waste food from community bins and further spread the waste. The stray animals can also be seen at dumping site (Fig. 2). This indicates the failure of MSW management system in Rishikesh. The Municipal Corporation Rishikesh has total 91 vehicles for the transportation of waste. This includes Tricycles (80), Tata Ace (2), JCB (1), Tractor (4), Truck (2), and Lifter (2). Fig. 3 shows images of some of these vehicles used for transporting MSW by Municipal Corporation of Rishikesh.
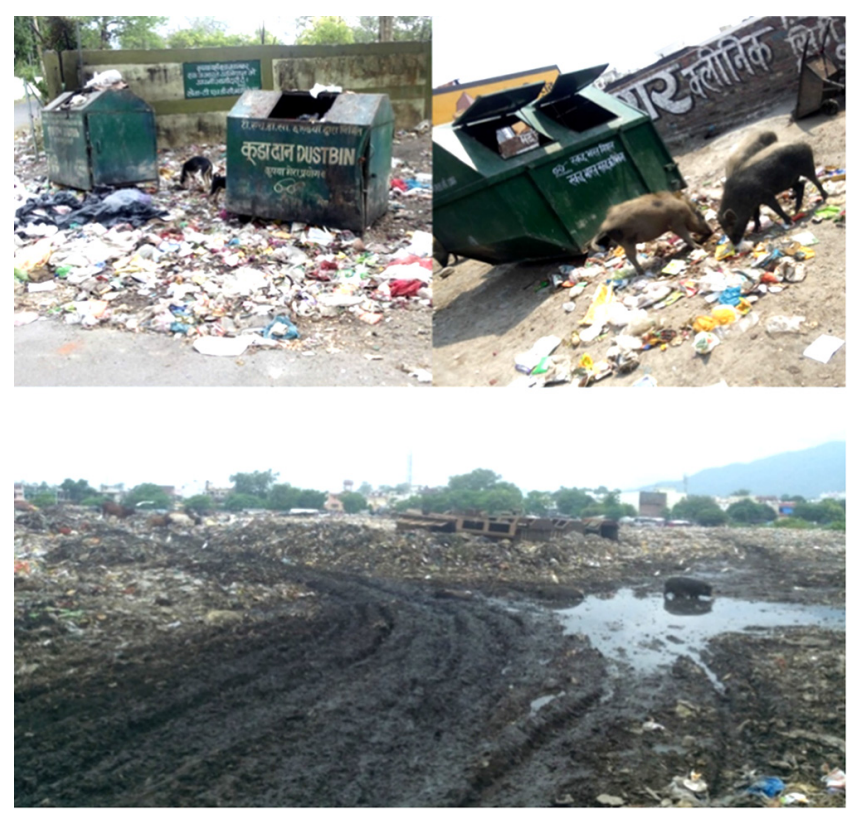

Fig. 2. Images of community bins (top) and MSW dumping site (below).

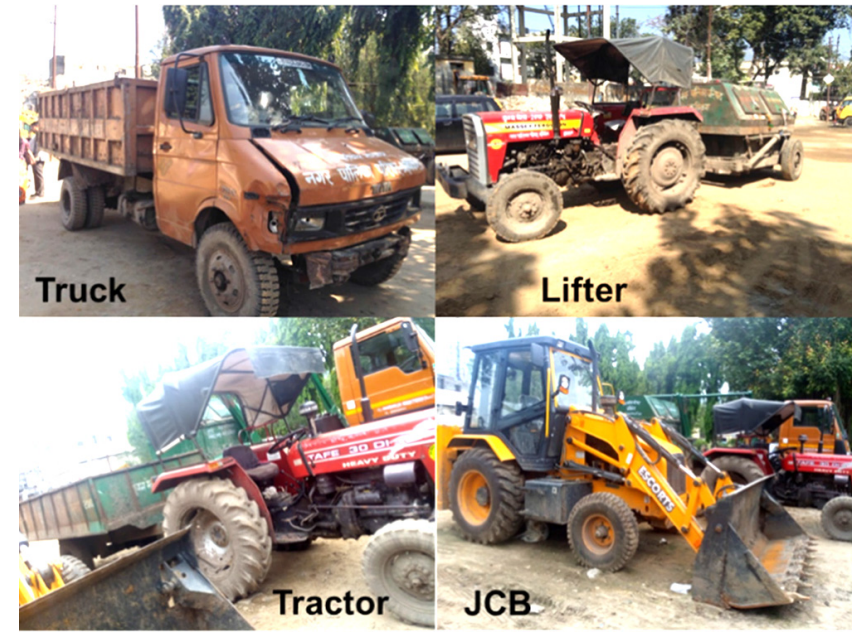

Fig. 3. Vehicles used for transporting the MSW to the dumpsite.

\subsection{Household Waste Characterization}

\subsubsection{Household waste generation rate}

The quantity and quality of wastes generated from households varies, according to income, food habits, number of family members (family size) and their age, life style, educational and occupational status [8, 9]. In this study, 329 solid waste samples from 47 households, involving a total population of 220 were collected. A total of $374.263 \mathrm{~kg}$ of waste is collected during the survey. Table 2 shows the results of descriptive statistics of the waste samples collected from 47 households. The average generation of waste from a household was $0.26 \pm 0.08 \mathrm{~kg} / \mathrm{c} / \mathrm{d}$ with an average 4.68 residents/household. The minimum and maximum values of generated waste are 0.134 and $0.528 \mathrm{~kg} / \mathrm{c} / \mathrm{d}$, respectively, which indicate significant variability of per capita waste generated by different households. The data set is moderately skewed right (skewness $=+0.832$ ). The value of kurtosis $(<3)$ indicates the distribution is platycurtic i.e. lower and broader centre peak with shorter and thinner tails.

Table 3 compares the household waste generation rates from different cities of world. It could be seen from Table 3 that the per capita waste generation rate in Rishikesh is very similar to other cities of developing countries such as Beijing, Suzhou,

Table 2. Descriptive Statistics of Household Waste Generation Rates

\begin{tabular}{lc}
\hline \multicolumn{1}{c}{ Parameters } & Household waste generation rate $\mathbf{( k g} / \mathbf{c} / \mathbf{d})$ \\
\hline Mean & 0.2597 \\
Standard error & 0.0121 \\
Standard deviation & 0.0832 \\
Sample variance & 0.0069 \\
Kurtosis & 1.0968 \\
Skewness & 0.8326 \\
Range & 0.3935 \\
Minimum & 0.1340 \\
Maximum & 0.5276 \\
Count & 47 \\
\hline
\end{tabular}


Table 3. Household Waste Generation Rate and Contribution of Food Waste (\%) from Different Cities of World

\begin{tabular}{|c|c|c|c|}
\hline City (Country) & Household waste generation $(\mathrm{kg} / \mathrm{c} / \mathrm{d})$ & Food waste (\%) & References \\
\hline Rishikesh (India) & 0.26 & 57.3 & This study \\
\hline Beijing (China) & 0.23 & 69.3 & [20] \\
\hline Suzhou (China) & 0.28 & 65.7 & [9] \\
\hline Bolgatanta (Ghana) & 0.21 & 61 & {$[21]$} \\
\hline Takoradi (Ghana) & 0.7 & 61 & {$[21]$} \\
\hline Cape Haitian city (Haiti) & 0.21 & 66.5 & {$[22]$} \\
\hline Mexicali (Mexico) & 0.981 & - & [10] \\
\hline Dublin (Ireland) & - & 40.48 & {$[23]$} \\
\hline Wales (England) & - & 26.79 & {$[24]$} \\
\hline
\end{tabular}

Bolgatanta, Cape Haitian city except Takoradi. The waste generation rate is very high in case of Mexicali city $(0.981 \mathrm{~kg} / \mathrm{c} / \mathrm{d})$, which is comparatively developed city.

\subsubsection{Composition of household waste}

The collected household waste was composed of organic or food waste (vegetables and fruits waste, leftover food, fish and meat wastes), plastic and polythene waste, paper and cardboard waste, glass and ceramic wastes and other wastes such as metal waste, clothes etc. Fig. 4 shows the percentage composition of household waste collected during the survey. The largest component, which accounted to $57.3 \%$ was found to be the food or organic waste. This is very high when compared to the developed cities such as Wales and Dublin, which has only 26.79 and $40.48 \%$ food waste, respectively (Table 3).

The composition analysis of household waste indicates that the major portion of the waste i.e. organic waste (57.3\%) is easily biodegradable and can be managed at household or community level through compositing.

\section{- Organic waste - Plastic \& Polythene Others}

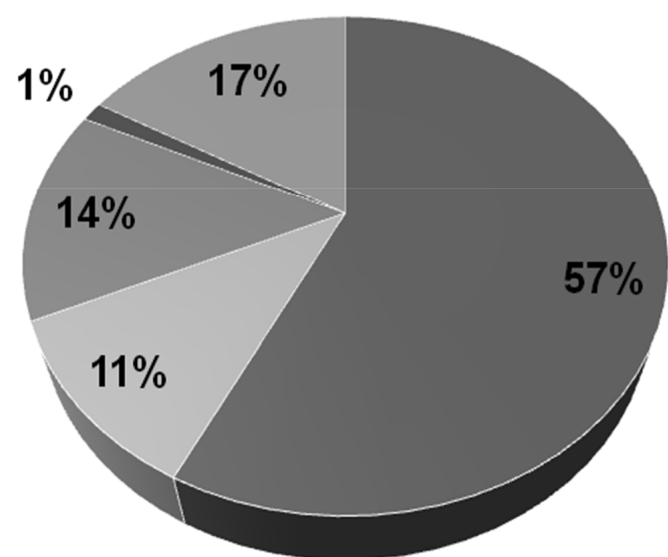

Fig. 4. Composition of household waste collected in the study. Other waste includes metal waste, clothes, etc.
3.2.3. Effect of family size on per capita household waste generation rate

In the surveyed households, the minimum persons in the family were two $(n=3)$ and the maximum persons in the household were $14(n=1)$. The frequencies of family size of $3,4,5,6$, 7 and 8 in the studied sample were 12, 10, 10, 6, 2 and 3 households, respectively. Fig. 5 shows the variation in per capita household waste generation rate with number of family members in a house. It could be clearly seen from the Fig. 5 that per capita household waste generation rate decreases with increasing family size.

For example, waste generation rate decreased from $0.37 \pm$ $0.07 \mathrm{~kg} / \mathrm{c} / \mathrm{d}$ for a family of 2 members $(n=3)$ to $0.19 \pm 0.03$ $\mathrm{kg} / \mathrm{c} / \mathrm{d}$ for a family of 8 members $(n=3)$. This indicates the environmental importance of Indian traditional group living system i.e. one family one kitchen. Previous studies also indicate the similar relationship between the household waste generation rate and family size [9-11].

The per capita household waste generation rate according to family size was further subjected to ANOVA test for statistical

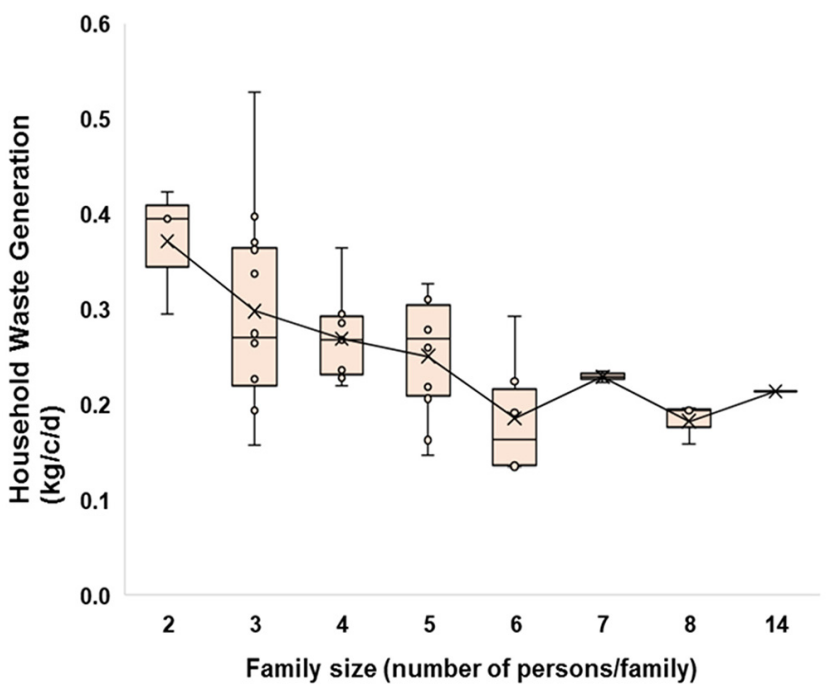

Fig. 5. Box-Whiskers plot showing the relationship between family size and per capita household waste generation rate. 
Table 4. ANOVA Test between Family Size Group and per Capita Household Waste Generation Rate

\begin{tabular}{|c|c|c|c|c|c|}
\hline \multicolumn{6}{|c|}{ Summary Table } \\
\hline Groups (family size) & Count & & & Average $(\mathrm{kg} / \mathrm{c} / \mathrm{d})$ & Variance \\
\hline$\leq 3$ & 15 & & & 0.313 & 0.010 \\
\hline $4 \leq 5$ & 20 & & & 0.260 & 0.003 \\
\hline$>5$ & 12 & & & 0.194 & 0.002 \\
\hline \multicolumn{6}{|c|}{ ANOVA Table } \\
\hline Source of variation & SS & Df & MS & $\mathbf{F}$ & P-value \\
\hline Between groups (Family size) & 0.093 & 2 & 0.047 & 9.087 & 0.0005 \\
\hline Within groups & 0.225 & 44 & 0.005 & & \\
\hline Total & 0.318 & 46 & & & \\
\hline
\end{tabular}

Table 5. ANOVA Test between Each Day of the Week and Household Waste Generation Rate

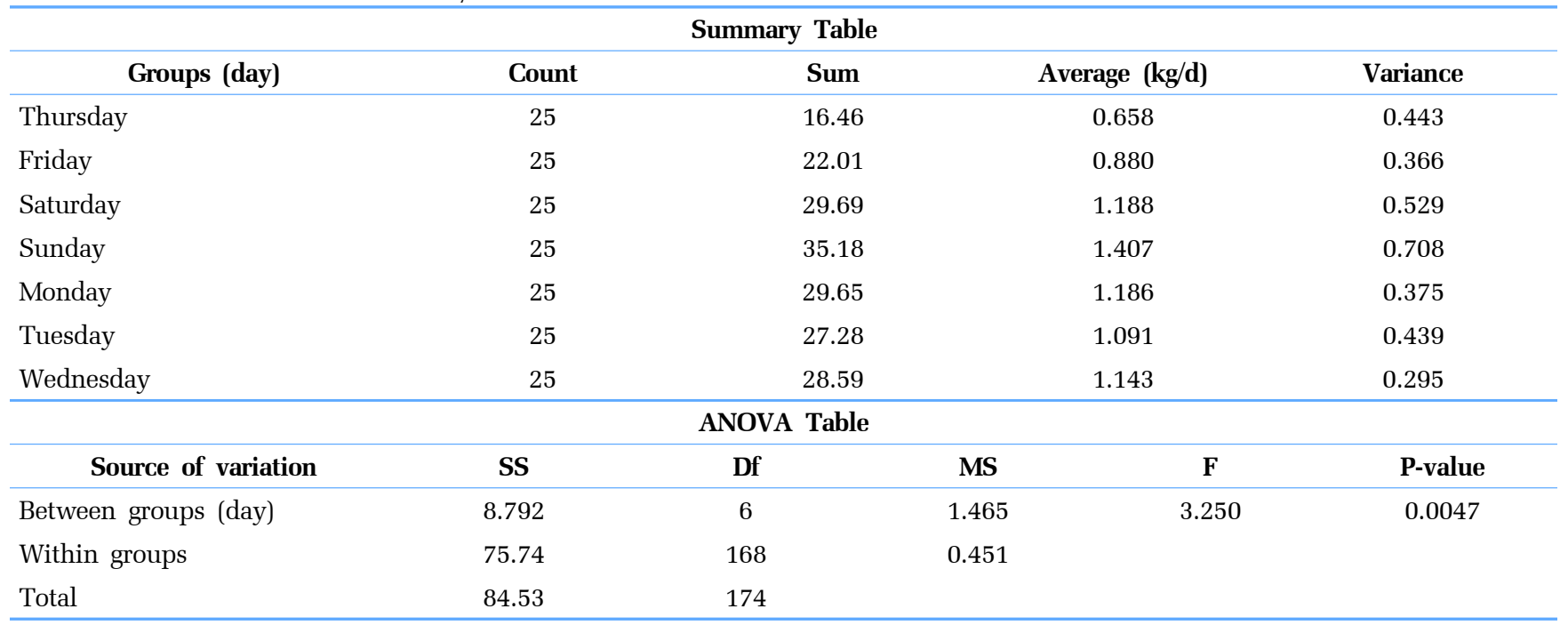

analysis. The results of ANOVA test are presented in Table 4, which indicate significant relationship between family size and household waste generation $(p<0.05)$. The average waste generation rate decreased from 0.313 to $0.194 \mathrm{~kg} / \mathrm{c} / \mathrm{d}$ when family size increased from 3 to $>5$. It is well known that the family size in Indian metro cities such as Delhi, Kolkata, Mumbai etc. is smaller than other cities. For example, the average family size in India is 5 while in Hyderabad, a metro city is 4 [12]. This could be the major factor for the higher per capita MSW generated by all the Indian metro cities (> $0.5 \mathrm{~kg} / \mathrm{c} / \mathrm{d}$ ) than Rishikesh.

\subsubsection{Effect of week days on household waste generation rate}

To understand the effect of each day of the week (Monday to Sunday) on household waste generation rate, the data set of samples collected in the first phase of the study was analysed through one-way ANOVA test. The results of ANOVA test are presented in Table 5. It is clearly evident from Table 5 that there is significant difference between each day of week and household waste generation rate $(p<0.05)$. The maximum waste generated $(1.407 \mathrm{~kg} / \mathrm{d})$ by a household is on Sunday and the least was generated $(0.356 \mathrm{~kg} / \mathrm{d})$ on middle of the week i.e. Thursday. It is quite understandable that in India people usually do shopping on weekends or holidays. Mostly we have six working days (Friday to Saturday) and one holiday i.e. Sunday in a week. Therefore, it is expected that accumulation of waste such as packaging materials would be more on Sundays. Similar results of household waste generation rate in China were reported by $\mathrm{Gu}$ et al. [9]. The authors observed that the household waste generation rate was higher on weekends (Saturday-Sunday) compared to week days (Monday-Friday).

\subsection{Issues of Current MSW Management System and Recommendations for Developing a Sustainable SWM System in Rishikesh}

\subsubsection{Segregation at source}

Waste segregation at source for example at household level is a critical issue for the sustainable management of MSW. Considering its importance, the waste should be segregated into two categories: (a) biodegradable and (b) non-biodegradable according to the MSW Management Rules 2000 notified by Ministry 
of Environment, Forest and Climate Change, Government of India. The MSW management rules 2000 have been recently revamped in 2016 and renamed as Solid Waste Management (SWM) Rules 2016. According to new rules, waste should be segregated into three categories: (a) Biodegradable; (b) Non-biodegradable and (c) Domestic Hazardous Waste. However, source segregation is not practiced at all in the existing scenario at Rishikesh. In general, people (residents) are not aware of the importance of waste segregation and their participation is nil. Therefore, people must be educated, aware and sensitized about the importance of segregation of household waste at source. They should also be educated to segregate waste into the three categories as mentioned in SWM Rules 2016.

Informal sectors such as rag-pickers play important role in segregation of recyclable waste in most of the Indian cities including Rishikesh. The Municipal Corporation should include them into the loop for managing the MSW. Formalization of rag-pickers and other informal sectors such as waste collectors and recycling industries has also been proposed in the SWM Rules 2016.

\subsubsection{Collection efficiency}

Poor MSW collection efficiency is another challenging issue in Rishikesh. At present, the collection efficiency is only $60 \%$ of the total MSW generated in Rishikesh compared to $70-90 \%$ in the major metro cities of India [13]. There should be $100 \%$ door-to-collection to improve the overall collection efficiency. There could be multiple factors for poor collection efficiency. Inadequate infrastructure (shortage of community bins and vehicles, and poor roads) and poor management (un-optimized root, improper bin collection systems and schedule) are the critical factors affecting collection efficiency [14-17]. In Rishikesh, community bins are not enough to cover the city. Moreover, the bins are not located with proper planning, which results in unequal distance of community bins. The community bins were found to be overloaded in most of the places during the field visit (Fig. 2). There was no separate bin for biodegradable or non-biodegradable waste. Littering of household solid waste has been observed during the field visit in the city, which is an outcome of poor collection efficiency, shortage of community bins and lack of awareness among the citizens. In the SWM rules 2016, littering of waste is offensive and the ULBs are empowered for spot fine in case they find anyone littering the solid waste. However, this has not been implemented so far in the Rishikesh city by the ULB. The major limitations for inadequate community bins and poor collection efficiency cited by the ULB were the lack of infrastructure, limited manpower and financial constraints.

\subsubsection{Disposal of waste}

This is the most neglected area of MSW management in India as about $90 \%$ of the MSW is disposed unscientifically to open dumping sites [18]. The current waste disposal in Rishikesh is unsound as un-segregated waste is dumped in to the open dumping site. Moreover, the dumping site is not scientifically managed in the Rishikesh. Open dumping at land is prone to flooding during rain and it could be the major source of surface water contamination. There is a high risk of ground water con- tamination via leachate percolation in open dumping site. Unscientific management of solid waste is a serious health hazard for the residents of the city. There is a high risk of spreading the communicable diseases for example Dengue, Typhoid, Malaria etc., which are very common in India and other South Asian countries during rainy season. Therefore, there is an urgent need to address the scientific disposal of MSW in Rishikesh. A new site for the scientific disposal of MSW has been identified by the Rishikesh ULB. However, the local residents near the proposed MSW disposal site are doing protest, which aggravate the problems of ULB. The novel technologies for energy recovery such as incineration and pyrolysis should also be explored by the ULB. Apart from the landfilling, the ULB should encourage citizens to compost the biodegradable waste at community level to reduce the overall volume of waste to be disposed at dumping/landfill site.

\subsubsection{Future planning for MSW management}

The Rishikesh city is growing rapidly and therefore a strategic planning is needed to address the MSW management. Considering the importance of the city as tourist and pilgrimage site a good city sanitation plan is necessary in near future. The city sanitation plan should address the key issues identified above and consider the recently revamped MSW Management Rules (SWM Rules 2016) by Ministry of Environment, Forest and Climate Change, Government of India. The ULB should involve all the stakeholders such as citizens, local authority, public figures, public representatives (Member of Parliament, Member of Legislative Assembly etc.), representative from informal sectors, media representatives, representative from health department, NGOs for future planning of MSW management in the city. Each stakeholder can play a significant role in MSW management in the city. Considering the financial limitations of municipality, it is highly desirable that the ULB implement the public private partnership (PPP). In Indian scenario, the PPP model in MSW management has not been popularized so far and therefore, no success story can be cited [19]. ULB should organize the awareness programs in regular interval for the citizens where the importance of household waste segregation, household hazardous waste management, and their role in keeping the city clean should be addressed.

\section{Conclusions}

The study indicates that the MSW management system in the Rishikesh city is unsound. The key issues identified include: no source segregation of waste; poor collection efficiency; unscientific disposal of waste. The city generates about 10,950 MT of MSW every year with $0.278 \mathrm{~kg} / \mathrm{c} / \mathrm{d}$. The household waste generation rate is $0.26 \mathrm{~kg} / \mathrm{c} / \mathrm{d}$, which is almost half when compared to metro cities of India. The family size affects the household waste generation rate. The maximum household waste is generated on Sundays compared to other days of week. The major portion of household waste generated in the city is biodegradable (57\%), which can be easily handled and converted to compost. This will further reduce the land requirement for 
disposal of sanitary waste. It is suggested that the city needs a systemic planning to address the key issues related to MSW management.

\section{Acknowledgments}

Authors would like to thank Executive Officer, Sanitory Inspector and other staff of Nagar Palika Parishad Rishikesh for providing data and extending their support for smooth field survey.

\section{References}

1. Alam T, Kulkarni K. Municipal solid waste management and its energy potential in Roorkee city, Uttarakhand, India. J. Inst. Eng. India Ser. A. 2016;97:9-17.

2. CPHEEO. Municipal solid waste management manual part II. 2016a.

3. Mani S, Singh S. Sustainable municipal solid waste management in India: A policy agenda. Procedia Environ. Sci. 2016;35:150-157.

4. Agarwal J, Jain S. Scope of power generation from MSW of Uttarakhand State. TEJAS. 2017;2:49-54.

5. Kumar H, Sah BL. Current scenario of solid waste management in Nainital town. Int. J. Manage. Soc. Sci. Res. 2015;4:15-21.

6. Tewari G, Bhatt D, Junne S, Mundhe R, Parale S, Baig MMV. Municipal solid waste management in Nainital, Uttarakhand: A case study. Quest 2013;7:288-295.

7. MNRE (Ministry of New and Renewable Energy). Power generation from municipal solid waste. $20^{\text {th }}$ Report of Standing Committee on Energy, 2015-16.

8. Sujauddin M, Huda MS, Hoque ATM. Household solid waste characteristics and management in Chittagong, Bangladesh. Waste Manage. 2008;28:1688-1695.

9. Gu B, Wang H, Chen Z, et al. Characterization, quantification and management of household solid waste: A case study in China. Resour. Conserv. Recycl. 2015;98:67-75.

10. Ojeda-Benítez S, Vega CA, Marquez-Montenegro MY. Household solid waste char-acterization by family socioeconomic profile as unit of analysis. Resour. Conserv. Recycl. 2008;52:992-999.
11. Thanh NP, Matsui Y, Fujiwara T. Household solid waste generation and characteristic in a Mekong Delta city: Vietnam. J. Environ. Manage. 2010;91:2307-2321.

12. Kundu D. "Cities for All" a report on $11^{\text {th }}$ Metropolis World Congress Hyderabad. 2014 (www.niua.org/sites/all/files/cites_ for_all.pdf).

13. CPHEEO. Municipal solid waste management manual part III. $2016 \mathrm{~b}$.

14. Hazra T, Goel S. Solid waste management in Kolkata, India: Practices and challenges. Waste Manage. 2009;29:470-478.

15. Moghadam MRA, Mokhtarani N, Mokhtarani B. Municipal solid waste management in Rasht City, Iran. Waste Manage. 2009;29:485-489.

16. Henry RK, Yongsheng Z, Jun D. Municipal solid waste management challenges in developing countries - Kenyan case study. Waste Manage. 2006;26:92-100.

17. Guerrero LA, Maas G, Hogland W. Solid waste management challenges for cities in developing countries. Waste Manage. 2013;33:220-232.

18. Das D, Srinivasu M, Bandyopadhyay M. Solid state acidification of vegetable waste. Indian J. Environ. Health 1998;40:333-342.

19. Joshi R, Ahmed S. Status and challenges of municipal solid waste management in India: A review. Cogent Environ. Sci. 2016;2:1139434

20. Qu XY, Li ZS, Xie XY, Sui YM, Yang L, Chen Y. Survey of composition and generation rate of household wastes in Beijing, China. Waste Manage. 2009;29:2618-2624.

21. Miezah K, Obiri-Danso K, Kádár Z, Fei-Baffoe B, Mensah MY. Municipal solid waste characterization and quantification as a measure towards effective waste management in Ghana. Waste Manage. 2015;46:15-27.

22. Philippe F, Culot M. Household solid waste generation and characteristics in Cape Haitian city: Republic of Haiti. Resour. Conserv. Recycl. 2009;54:73-78.

23. Dennison GJ, Dodd VA, Whelan BA. Socio-economic based survey of household waste characteristics in the city of Dublin, Ireland. I. Waste composition. Resour. Conserv. Recycl. 1996;17:227-244.

24. Burnley SJ, Ellis JC, Flowerdew R, Poll AJ, Prosser H. Assessing the composition of municipal solid waste in Wales. Resour. Conserv. Recycl. 2007;49:264-283. 